\title{
STRATEGI KIKI SULISTYO DALAM ARENA SASTRA INDONESIA
}

\author{
Dharma Satrya HD \\ Universitas Gadjah Mada \\ Yogyakarta, Indonesia \\ dharmastryahd@gmail.com
}

\begin{abstract}
This paper discusses Kiki Sulistyo's strategy for reaching position in Lombok literary field. This research applied phenomenology and structural analysis method. Data were gathered by interview and objectification from social structure. The style of the writers' poems and his consciousness toward Lombok were analyzed by phenomenology. The research result shows that Lombok literary field is denoted as the economy upside. Kiki Sulistyo denounces the world economy, thus moving within the production of a restricted arena. Kiki Sulistyo created literature as a movement, so he formed Akar Pohon community. Through this community, he generates a young poet and simultaneously undertakes a project of publishing works. Two anthologies of poetry he published brought him to the position of a legitimate poet. The legitimacy is given by poets, literary scholars, and institutions
\end{abstract}

Keywords: strategy, Kiki Sulistyo, literary field

\begin{abstract}
ABSTRAK
Tulisan ini membahas strategi kiki Sulistyo dalam meraih posisi di arena sastra Indonesia. Tulisan ini menggunakan metode analisis fenomenologi dan struktural. Data diperoleh melalui wawancara dan objektivasi melalui stuktur sosial. Gaya puisi Kiki Sulistyo dianalisis dengan analisis fenomenologi dengan melihat kesadaran penyair mengenai Lombok. Hasil penelitian adalah arena sastra Lombok dapat dikatakan sebagai dunia ekonomi terbalik. Kiki Sulistyo melakukan penyangkalan terhadap dunia ekonomi, sehingga bergerak di dalam produksi arena terbatas. Kiki Sulistyo menjadikan sastra sebagai sebuah gerakan, sehingga ia membentuk komunitas akar pohon. Melalui akar pohon, ia mencetak penyair muda dan sekaligus melakukan proyek penerbitan karya. Dua antologi puisi yang terbitkannya mengantarkan dia mencapai posisi penyair legitimasi. Legitimasi tersebut diberikan oleh sasama penyair, akademisi sastra, dan institusi.
\end{abstract}

Kata Kunci: strategi, Kiki Sulistyo, arena sastra 


\section{PENDAHULUAN}

Kajian mengenai sastra Indonesia tidaklah statis. Ia mengikuti perubahan paradigma dalam jagat akademik sastra. Perubahan ini dapat dilihat pada trendnya kajian sosiologi sastra Bourdieu yang merupakan respon terhadap sosiologi sastra model Goldman. Kajian sastra Indonesia dengan perspektif Bourdieu menemukan dua arah analisis, yaitu analisis struktur dan analisis fenomenologi. Analisis pertama menempatkan kajian terhadap sastra Indonesia dalam paradigma struktur (Astika 2013, Jatmiko 2013, Satrya 2014, Anwar 2015, Karnanta 2015, Nugraha 2015, Safitri 2015, Sulistyo 2015, dan Zamzuri 2016). Analisis yang kedua menempatkan kajian terhadap sastra Indonesia ke dalam paradigma fenomenologi. Kedua paradigma itulah yang membentuk cara berfikir Pierre Bordieu. Kecenderungan yang kedua ditunjukkan oleh Satrya (2015) dalam tulisannya mengenai Lombok dengan kasus komunitas sastra di Lombok. Dengan paradigma yang pertama tersebut, struktur menentukan posisi penyair atau sastrawan. Hubungan antara struktur arena dan struktur kekuasaan membentuk Paranggi, Emha Aninun Najib, dan Imam Budhi Santosa menjadi penyair terkonsekrasi dan struktur arena sastralah yang membuat Suparto Brata dan Andrea Hirata gagal meraih posisi sebagai sastrawan terkonsekrasi atau memperoleh legitimasi spesifik. Sastrwan yang berhasil meraih legitimasi spesifik ditunjukkan oleh Adila (2016) dalam disertasinya tentang A.A. Navis dalam sastra Indonesia.

Para peneliti sastra Indonesia cenderung membahas penyair atau sastrawan Indonesia yang menasional, sedangkan penyair ditingkat lokal diabaikan. Hal ini menunjukkan bahwa peneliti sastra Indonesia masih terhegemoni sastra yang terpusat di satu ruang sastra seperti kota. Sementara sastra Indonesia, sebagaimana dijelaskan oleh Tony Day dan Keith Foucher (2006, h.12), harus berusaha menggugat sastra nasional yang otoritatif. Dengan perspektif pascakolonial, Derk (2006) menawarkan sastra Indonesia yang multipusat dan Jakarta adalah salah 
satu pusat itu. Asumsi yang dibangun dalam perspektif tersebut memberikan ruang bagi sastra Indonesia daerah sebagai pusat sastra untuk diangkat ke permukaan. Dalam konteks inilah, para sastrawan di daerah perlu diangkat sebagai agen yang juga membentuk identitas sastra Indonesia. Sastrawan Indonesia di daerah yang perlu dilihat posisinya adalah Kiki Sulistiyo, penyair kelahiran Lombok. Penyair Lombok penting untuk diteliti dengan alasan bahwa Lombok adalah salah satu daerah yang dapat dikatakan tidak masuk ke dalam daerah yang perlu diperhitungkan dalam peta sastra Indonesia. Penelitian ini memfokuskan penyair Lombok, Kiki Sulistyo. Tujuan dari penelitian ini mengetahui strategi Kiki Sulistyo dalam Arena Sastra di Lombok.

\section{TEORI DAN METODOLOGI}

Untuk dapat mengetahui strateginya dilakukan analisis struktur (sosial), analisis fenomenologis, dan hubungan antara karya dengan posisi yang ditempati di dalam arena. Analisis tersebut menggunakan teori Pierre Bourdieu dalam Arena Produksi Kultural dan
The Rules of Arts. Dalam buku tersebut, Bourdieu meneliti arena sastra Prancis. Bourdieu menemukan bahwa dunia sastra di Prancis adalah dunia ekonomi terbalik. Tulisan ini melihat dunia sastra di Lombok dengan asumsi tersebut. Pertanyaan yang mumncul adalah apakah dunia sastra di Lombok adalah ekonomi terbalik? atau apakah sebagai penyair, Kiki Sulistyo melakukan penyangkalan terhadap ekonomi?. selain itu, tulisan ini akan berusaha mencari hubungan antara posisi yang diraih dengan logika praktik atau pilihan-pilihan yang dimabil Kiki Sulistyo. Pertanyaan itulah yang dibahas dalam tulisan ini.

\section{HASIL DAN PEMBAHASAN}

Dualitas Hierarki, Kondisi Arena Produksi Kultural dalam Sastra di Lombok

Dualitas hierarki ini adalah hierarki kultural genre-genre dan hierarki cara menggunakan genre sastra. Ada yang berada di puncak hierarki, seperti drama, kemudian diikuti oleh novel dan puisi. Drama menghasilkan keuntungan ekonomi 
lebih besar dibandingkan dengan novel dan puisi. Pementasanpementasan drama selalu dihadiri banyak penonton. Pementasanpementasan yang dilakukan oleh Teater Putih dan Teater Embrio, misalnya sampai tiga malam berturut-tutut di Gedung Tertutup taman budaya Mataram, mampu menarik 500 penonton setiap malamnya. Teater Putih, teater pelajar, Teater Kamar, dan Teater Embrio mementaskan drama satu kali dalam setahun. Dengan waktu produksi yang lama dan dengan tiket yang murah, pementasan drama tidak terlalu menguntungkan. Proses produksi yang terhitung lama sekitar satu hingga tiga bulan dengan penjualan tiket seharga Rp. 5000,00 tentunya tidak menghasilkan banyak keuntungan. Pementasan drama maksimal mampu meraih jumlah penonton sampai 1500 penonton selama tiga malam. Hasil penjualan tiket untuk pementasan drama maksimal sampai tujuh juta. Basis penonton pementasan adalah siswa, mahasiswa, dan orang tua mahasiswa. Keuntungan yang lebih banyak diperoleh dalam festival teater modern pelajar yang diselenggarakan oleh Teater Putih.

Festival teater pelajar yang diselenggarakan Teater Putih setiap tahun menghasilkan lebih banyak keuntungan secara ekonomi. Hasil penjulan tiket dalam acara festival teater pelajar maksimal dua puluh juta selama satu minggu. Keuntungan itu bukanlah keuntungan pribadi, tetapi keuntungan yang kemudian digunakan untuk keberlanjutan organisasi. Sebab, semua anggotanya adalah mahasiswa. Teater memiliki audien sendiri, seperti dari kalangan pelajar dan mahasiswa. Jika dibandingkan dengan novel, novel relatif memiliki keuntungan lebih sedikit dibandingkan teater. Novel dicetak dalam jumlah terbatas dan dengan keuntungan yang sedikit. Namun, apabila penulis novel sedikit lebih politis seperti yang dilakukan Salman Faris dan Eva Nourma, dalam momen tertentu, dia mendapatkan keuntungan yang cukup. Sebab, kekerasan simbolik menjadi strategi penjualan novel kepada mahasiswa. Salman Faris tidak hanya dikenal sebagai novelis dan dosen, tetapi di juga sebagai konsultan seni. Sebagai 
novelis, dia sudah menulis lima judul novel. Salman Faris sampai sekarang belum mendapatkan legitimasi spesifik. Penyair generasi muda menilai novel Salman Faris tidak memenuhi kriteria estetik pada tatarn cara bernarasi. ${ }^{1}$ Novel Johan Mahyudi dan Nuriadi lebih dinilai sebagai novel popular dengan mengedapankan tema cinta. Para penulis yang tersebut merupakan seorang dosen sastra. Para penulis yang sekaligus dosen cenderung lebih politis dan ekonomis. Hal itu dipertegas dengan diberikannya Agus Fn. penghargaan sebagai sastrawan oleh Balai Bahasa Nusa Tenggara Barat.

Posisi yang terakhir adalah puisi dan cerpen yang para agennya tidak mementingkan persoalan ekonomi dan politik. Penyair tidak mendapat banyak keuntungan dari penjualan puisi. Akan tetapi, secara simbolik, puisi dapat menempati hierarki tersebut. Jika dilihat dari audien yang ditujunya, drama dan novel sesuai dengan selera masyarakat umum. Nmaun, hal itu

1 Penilaian Kiki Sulistyo dalam sebuah wawancara Agustus 2016 berbeda untuk kasus puisi. Sebab, hal itu tidak semua audiens bisa menikmati puisi-puisi, misalnya puisi Sulistiyo. Sejak 2013, puisi mulai menguasai arena ketika komunitaskomunitas teater kehabisan aktor, terutama Teater Kamar ${ }^{2}$ dan Teater Embrio $^{3}$. Akar Pohon ${ }^{4}$ bermain dalam ranah universitas dan sekolah untuk membuat puisi semakin dekat dengan siswa. Hal itu dilakukan dengan cara mengajak membaca dan berdiskusi puisi yang selama ini kurang diajarkan di sekolah dan universitas. Sistem pendidikan perguruan tinggi belum mampu menghasilkan novelis atau cerpenis. Sebaliknya, dosen yang terobsesi menjadi penulis novel dan mahasiswa menjadi pembacanya. Di tangan Sulistiyo, puisi menjadi sebuah gerakan yang menghasilkan cukup banyak penyair muda pada kelahiran tahun 1990-an.

Tahun 2010-an menjadi momen bagi keberadaan dan

\footnotetext{
2 Teater Kamar ini diketuai oleh Saifullah Sapturi, seorang seniman taman budaya Mataram, NTB

3 Teater Embrio diketuai oleh Agus Wintarno (Winsa), seorang seniman taman budaya Mataram, NTB

4 Akar Pohon adalah komunitas sastra di bawah asuhan Kiki Sulityo, penyair kota Mataram
} 
kehadiran Sulistiyo dan Akar Pohon. Sulistiyo berpikir mengenai keberlanjutan dan kebertahanan diri pada puisi. Keberadaan manusia ada dalam cakrawala waktu. Cakrawala keberadaan Sulistiyo hadir sebagai horizon baru yang terlihat apabila dia berada di depan horizon tersebut. Keberadaan Sulistiyo merupakan peristiwa yang menyebabkan “ada'nya yang lain, yakni penyair atau cerpenis muda. Kemunculan akademisi baru dan calon penyair beserta dengan peristiwa yang melingkupinya lahir dari peristiwa yang diadakannya. Penulis lain tidak berpikir demikian. Oleh karena itu, dia tidak hanya berpikir pendek. Penulis novel tersebut tidak berada di depan "cakrawala waktu", tetapi hanyut di dalam "cakrawala waktu" sehingga diri dan karyanya "tenggelam" begitu saja dalam waktu. Setelah diberikan anugrah sastra oleh Balai Bahasa NTB, "waktu"nya Agus Fn berakhir sampai di waktu ia diberikan penghargaan. Setelah "waktu" itu, dia tidak lagi berada " $d i$ depan", tetapi berhenti "di belakang". Sebagai akibatnya, dia cenderung menjadi "pendak" "waktu"-nya. Namun, Sulistiyo mampu melihat pada yang "panjang". Salman Faris juga demikian, diatidak berpikir pada "yang panjang". Awal karirnya sebagai novelis, Salman jauh berpikir pada "yang panjang" dan membuatnya dinilai sebagai novelis yang idealis. Namun, cakrawala "waktu-"nya berakhir di tahun 2012. Hal itu dikarena dia tenggelam dalam waktu yang dia buat sendri. Setelah novel Kenari Mataram 2013, dia tidak berada di "depan cakrawala waktu", tetapi dia berada di dalamnya dan di belakangnya. Artinya, Salman Faris semakin politis dalam berkarya dengan bergerak di dalam produksi untuk "jangka pendek". Hal tersebut tentu tidak dikatakan sebagai ekonomi terbalik dalam pasar sastra.

Sebagai pasar, arena sastra Lombok belum bersifat komersial, tetapi kultural dan simbolik. Hal itu bisa dilihat dari perbedaan antara pasar tradisional dengan pasar yang dibuat oleh kapitalis. Pasar tradisional menyediakan aktivitas yang begitu "bergairah". Para ibu yang berjualan bertemu dengan ibu yang lain untuk berbicara tentang sanak keluarga, berbicara tentang masa lalu, lalu bergosip tentang masa 
kini, dan berkhayal tentang masa depan. Hal serupa berlaku bagi yang datang untuk membeli dan menyambung pembicaraan tentang waktu-waktu yang hilang dan tentang kenangan yang dimunculkan. Akan tetapi di pasar, para kapitalis hanya berproduksi demi komersial semata dan dalam kondisi demikian manusia seperti bukan dirinya lagi karena berjarak dengan yang dilakukannya. Artinya, manusia sepeti bukan manusia lagi, ibu-ibu yang masuk bukan lagi ibu yang cerewet dengan masa kini dan masa lalu, tetapi ibuibu yang bisu. Mereka seolah kehilangan gairah hidup. Hal ini karakteristik estetika kehidupan pasar. Hal itu merupakan gambaran pasar sastra di Lombok.

Para borjuis dan para dosen penulis bergerak dalam pasar modern, sedangkan para "pecundang", yang miskin secara ekonomi namun kaya secara simbolik, bergerak dalam pasar tradisi yang lebih bergairah, lebih dinamis, dan penuh dengan dialog. Bourdieu sendiri membicarakannya dalam membahas karya seni, terutama dalam pembahasannya tentang Manet. Seperti analogi pasar tersebut, Sulistiyo adalah gambaran pasar tradisional tersebut. Sementara itu, gambaran pasar kedua menggambarkan para bourjuis yang membawa barang demi sebuah kepentingan politis. Ibu-ibu dalam pasar tradisi tidak hanya karena soal barang yang akan dijualnya atau karena ingin membeli sesuatu. Nmaun, mereka datang demi terciptanya sebuah dialog tentang sesuatu yang menggelisahkan kaum ibu. Hal ini serupa dengan kegelisahan Kiki Sulityo sebagai seorang penyair yang memilih puisi sebagai jalan hidupnya. Di dalam perjalanannya sebagai penyair, dia bertemu dengan "yang lain" dan pertemuannya tentunya menghasilkan sebuah temuan. Temuan itu adalah terbentuknya komunitas sastra, yakni Akar Pohon.

\section{Pembentukan Akar Pohon sebagai Sebuah Strategi}

Komunitas lahir dari interaksiinteraksi yang terus dilakukan dan berkelanjutan. Ada kerinduan dari beberapa kawan-kawan untuk hidup berorganisasi seperti bagaimana mereka ketika mahasiswa. Kiki 
Sulistiyo dengan rutinitasnya berjalan kaki ke warung Jack di taman budaya. Dia berbincangbincang dengan para seniman. Suatu ketika, sekitar tahun 2008, dia dan beberapa kawannya berkumpul dan berinteraksi untuk mengumpulkan suatu ide. Kiki Sulistiyo adalah pendatang baru dalam dunia kepenyairan. Haryanto yang bergelut di Teater Putih dan Teater Embrio dan beberapa kawan teater seperti Jabo akhinya mendapat ide untuk membuat komunitas.

Nmaun, ada satu peristiwa yang mendahuli peristiwa tersebut, yaitu buletin Replika. Haryanto bersama Muh Ardian membuat buletin itu. Tujuannya adalah untuk menunjukkan satu gerakan sastra di Mataram. Nama penulis dan beberapa kawan di teater dipakai untuk struktur redaksi. Setiap terbitan, buletin tersebut diantar ke Taman Budaya, Balai Bahasa NTB, Perpustakaan Daerah, Perpustakaan Kota, SMAN 2 Mataram, dan senimanseniman. Akan tetapi, sayangnya, bulletin itu hanya terbit selama delapan edisi dalam waktu satu tahum. Hal ini dikarenakan tidak ada biaya penerbitan. ${ }^{5}$

Sebagai pendiri, Haryanto memakai honor mengajar sebanyak Rp 200.000 untuk menerbitkannya. ${ }^{6}$ Karena persoalan ekonomi, akhirnya bulletin tersebut bubar. Perjumpaan Haryanto perkali dengan Kiki Sulistiyo adalah ketika dia membawa buletin ke taman budaya. Di sanalah, Sulistiyo sering menghabiskan waktunya. Di Warung Jeck Taman Budaya, para seniman sering berkumpul untuk minum kopi. Bahkan, warung itu menjadi kantornya. Ada seniman pendatang baru alumnus STSI Bandung yang waktu itu belum mempunyai pekerjaan tetap, yaitu Jabo. Mereka mengidentifikasi diri bahwa mereka akan sulit berinteraksi. Mereka juga merencanakan produksi seni dengan para seniman yang sekaligus pegawai negeri sipil di taman budaya. Kedatangan Haryanto membawa bulletin, tentunya menjadi salah satu sebab yang dibicarakan oleh komunitas. Hal itu dipandang sebagai

\begin{tabular}{lrlll}
\hline 5 & Wawancara & dengan & Haryanto & 14 \\
November 2016 & & & \\
6 & Wawancara & dengan & Haryanto & 14 \\
November 2016 & & &
\end{tabular}


sebuah ruang dan gerakan sastra di Mataram.

Replika menjadi penting dalam mempertemukan Haryanto, Sulistiyo, Tjak S Parlan, dan Jabo. Sebagai orang teater, mereka pernah menjadi aktor. Haryanto mempunyai minat yang tinggi dalam membicarakan karya sastra. Begitu juga dengan Jabo, dia juga memiliki minat yang sama meski sebagai lulusan teater. Nama Kiki Sulistiyo sudah mulai dikenal orang sebagai penyair termasuk Tjak $\mathrm{S}$ Parlan yang seorang cerpenis.

Replika menjadi ruang bagi mereka untuk membicarakan atau membahas karya sastra. Namun, Replika tidak bertahan lama karena persoalan ekonomi. Dia terpaksa tidak terbit. Ruang bergeser dari Replika ke komunitas. Haryanto, Sulistiyo, Tjak S Parlan, dan Jabo membuat komunitas sastra yang bernama Akar Pohon. Awalnya, mereka bertiga. Oleh karena, mereka butuh orang yang akan mendesain terbitan, akhirnya mereka mengajak Tjak S Parlan7. Keempat orang tersebut memiliki latar belakang

7 Penuturan Haryanto ketika wawancara 14 November 2016 minat yang berbeda sehingga pada akhirnya dua diantaranya keluar dan membuat komunitas lain.

Jabo membuat laboratorium teater dan Haryanto memilih keluar dari komunitas tersebut. Jabo memilih menjadi guru. Akar Pohon kemudian dijalankan oleh dua orang tersebut. Mereka masuk ke universitas dan sekolah untuk menjaring anggota, mencari mahasiswa, dan siswa yang berbakat untuk diajak bergabung. Akar Pohon melahirkan penyair dan cerpenis muda kelahiran 1990an seperti Ilda Karwayu, Arianto Adipurwanto, Bayu Pratama, IIn Farliani, Marlinda Ramdhani, Bunga Damai Prasasti, Novita Hidayani, Lamuh Syamsuar, Atanasius Rony, Ismawati, Chaidir Amry, dan M Allan Hanaf. Penyair muda itu adalah buah tangan atau hasil didikan dari Akar Pohon yang terus menerus melatih mereka untuk menjadi penyair atau cerpenis.

$$
\text { Penyair-penyair muda }
$$
tersebut menjadi anggota yang setia dari Akar Pohon. Sekarang, keanggotaan Akar Pohon berjumlah enam belas orang, yaitu dua belas diantaranya yang telah disebutkan. 
Sementara, empat diantaranya adalah Budi Afandi, Irma Agrianti, Tjak S Parlan, dan Kiki Sulistiyo. Irma Agrianti termasuk pendatang baru di komunitas itu karena sebelumnya ia berdomisili di Yogyakarta dan pernah kuliah di Universitas Ahmad Dahlan. Artinya, Irma sudah lebih dulu mempunyai modal kepenyairan yang diperolehnya ketika dia di Yogyakarta. Bergabungnya Agrianti dan termasuk bergabungnya para pendiri ke dalam wadah yang disebut Akar Pohon adalah salah satu bentuk dan hasil tifikasi.

Dunia sastra yang digeluti oleh mereka adalah dunia sastra yang sudah diobjektifikasi. Dunia sastra sudah dibentuk oleh orang-orang yang sudah membangun tatanan. Bahkan, mereka sudah ada sebelum dia menjadi penyair. Orang yang bergelut dalam dunia sastra sudah tentu berhubungan atau berkumpul dengan sastra secara intens. Artinya, mereka bergaul dengan sesama orang sastra atau sesama penyair. Orangorang itu kemudian diklasifikasi sebagai penyair, cerpenis, atau novelis. Bahkan, klasifikasi itu lebih detail bahwa orang ini penyair borjuis, misalnya.

Tifikasi semacam itu membuat mereka memisahkah diri atau mengelompokkan diri sendiri dengan orang yang menurutnya ada dalam satu tifikasi. Hal itu terjadi dalam Akar Pohon. Mereka yang berkelompok adalah mereka yang dalam satu tipe, yaitu penyair dan cerpenis yang terpinggir secara ekonomi. Tifikasi itu dilakukan oleh Agrianti sehingga dia kemudian memilih bergaul atau berkelompok dengan para penyair dan cerpenis Akar Pohon. Mereka menyadari bahwa mereka tergabung dalam Akar Pohon sebagai penyair yang memperjuangkan sastra atau menghidupkan iklim sastra di Lombok.

Para penyair seperti mereka itu menyadari bahwa dirinya seorang penyair. Kesadaran itu membuat mereka terus menerus memproduksi karya sastra. Karya sastra tersebut selalu dikirim ke media lokal dan nasional. Pada gilirannya, mereka menerbitkan karya tersebut ke dalam bentuk buku. Para penyair dan cerpenis juga sudah menemukan 
kesadaran seperti itu. Sebuah kesadaran bersastra yang sudah mengalami tifikasi.

Para penyair itu juga mengetahui sejarah tentang dii dan perjuangannya. Mereka mengetahui ranah dan ruang sastra Indoensia. Misalnya, mereka membaca cerpencerpen dari harian Kompas yang kemudian diterbitkan menjadi buku. Cara produksi dan sirkulasi sastra yang demikian sudah mengalami objetivikasi. Pola seperti itu juga dipakai Akar Pohon. Ada karya yang dimaksudkan untuk diterbitkan dalam bentuk buku. Nmaun, ada juga karya yang dipublikasi melalui media. Selanjutnya, karya itu diterbitkan menjadi sebuah antologi bersama.

Kesadaran seperti itu sudah berada dalam pikiran para anggota Akar Pohon. Kesadaran ini tentu saja berbeda dengan penyair generasi tahun 1950-an. Penyair Sulaiman Saleh, yang usianya sekitar 70-an, membiarkan karya-karyanya menjadi artefak di rumah. Suatu ketika, Kiki Sulistiyo mengunjungi beliau dan meminta karyanya diterbitkan. Akan tetapi, beliau belum mau menerbitkannya ${ }^{8}$.

Kesadaran demikian juga dimiliki oleh cerpenis Imtihan Taufan. Sebelum meninggal, dia tidak mau menerbitkan cerpen-cerpennya. Akan tetapi, setelah dia meninggal dunia tahun 2014, karya-karyanya mulai dibicarakan dan oleh kawankawannya. Kemudian, karyanya diterbitkan pada tahun 2015. Cerpenis Geger Prahara juga demikian. Dia belum menerbitkan cerpen-cerpennya. Dia secara intens mengirimkan cerpen ke media-media lokal dan beberapa media nasioanal. Akan tetapi, dia juga belum mau menerbitkan menjadi buku.

Namun, kesadaran yang tinggi untuk menerbitkan karya dimiliki oleh novelis yang berprofesi sebagai dosen atau pengajar. Dosen-dosen tidak ragu untuk menerbitkan karya dalam bentuk novel. Kadang kala, karyanya tidak direspon dengan baik oleh beberapa pihak. Hal ini

\footnotetext{
8 Penuturan Kiki Sulistyo ketika wawancara melalui elektronik pada tanggal 27 Desember 2016
} 
dikarenakan kualitas karyanya yang dianggap tidak "layak baca". 9

Perbedaan perspektif dalam melihat sastra terlihat antara Akar Pohon dengan dosen yang sekaligus penulis. Mereka tidak berinteraksi dan berkomunikasi sehingga eksistensi mereka berbeda dalam ruang yang sama. Akar Pohon mendapatkan eksistensinya ketika mereka berinteraksi dan berkomunikasi secara intens. Komunikasi iu dilakukan melalui komunitas atau pergaulan dengan sesama penyair dan cerpenis di lingkungan yang sama. Sebagai contohnya adalah lingkungan taman budaya. Para penulis novel enggan untuk sekedar minum kopi bersama di warung Jack Taman Budaya. Suatu ketika, Kiki Sulistiyo mengatakan kepada penulis tentang akademisi atau sastrawan borjuis yang susah untuk bergabung dengan para penyair. Namun, Akar Pohon tetap berjalan tanpa keterlibatan akademisi.

\footnotetext{
9 Penilaian seorang penyair, Muh Ardian Kurniawan dalamwawancara elektronik pada tahun 2016
}

Akar Pohon menjadi dunia "di sini”. Penulis yang lain menjadi dunia yang "di sana”. Dunia "sekarang” bagi mereka berbeda. Sekarang yang "di sana" dan yang "di sini" berbeda. Hal ini terlihat dalam proyek sastranya. Objektifikasi dunia sastra yang tertanam dan tertata di antara keduanya berbeda. Bahkan, keberadan mereka juga berbeda meski mereka dalam ranah atau ruang yang sama. Begitu juga, mereka berbeda walaupun dalam "waktu" atau momen yang sama.

Sebagai contoh kasus dari hal tersebut, misalnya, adalah proyek penerbitan sastra. Akar Pohon secara intens menerbitkan antologi puisi. Antologi itu bisa bersifat individu atau antologi bersama. Sementara itu, penerbitan karya para dosen bersifat temporal. Legitimasi keduanya berbeda. Pertama adalah legitimasi borjuis untuk dosen yang berprofesi penulis. Kedua adalah legitimasi spesifik untuk komunitas Akar Pohon.

Persoalan yang penting untuk dibicarakan adalah kekuatan dari keanggotaan Akar Pohon tersebut. Artinya, hal ini juga berhubungan 
dengan aturan yang mengikat antara anggota yang bersifat longgar atau tidak longgar. Mataram dan Lombok pada umumnya tidak memiliki banyak komunitas, baik komunitas sastra atau seni. Hal ini menyebabkan lintas arena dan ruang kompetisi yang sangat sedikit.

Untuk arena teater, ada tiga komunitas yang dominan, yaitu Teater Putih, Teater Kamar, dan Teater Embrio. Komunitas tari, perupa, dan musik jauh lebih sedikit bila dibandingkan dengan teater. Komunitas sastra baru yang muncul sebanyak tiga, yaitu Akar Pohon, Pasir Putih, dan Rabu Langit. Ketiganya digagas Sulistiyo. Di kampus, komunitas sastra tidak muncul dan berdiri sendiri. Namun, komunitas itu berada dalam organisasi teater.

Berdasarkan keadaan dan ruang yang demikian, hal itu membuat anggota Akar Pohon menjadi terikat keanggotannya secara kuat. Artinya, kepenyairan anggota mendapatkan eksistensinya sebagai penyair di dalam dan melalui Akar Pohon. Namun, hal itu menjadi pengecualian untuk kasus Irma
Agrianti, yang sebelumnya mengenal dunia sastra di Yogyakarta. Kekuatan ikatan keanggotaan Akar Pohon dapat dilihat dari interaksi di dalamnya. Hal ini terutama terlihat dari interaksi yang terjadi seperti pada pertemuan tatap muka.

Artinya, mereka secara terus menerus berlatih dan dilatih oleh Sulistiyo. Ruang interaksi yang terus menerus diadakan Sulistiyo inilah yang memperkuat keanggotaan Akar Pohon. Melalui interaksi tersebut, mereka menjalankan prinsip tifikasi, yang dijadikan dasar untuk memahami orang lain. Kedua belas anggota Akar Pohon relatif masih muda. Mereka adalah lulusan perguruan tinggi, mahasiswa, dan siswa, yang mempunyai kesadaran bahwa mereka sedang belajar untuk menjadi penyair. Mereka tidak mendapatkan pelajaran menjadi penyair di dalam ruang sekolah formal seperti sekolah dan perguruan tinggi. Meskipun mereka diberi fasilitas melalui mata pelajaran sastra dan penulisan kreatif sastra, mereka tetap membutuhkan komunitas.

Keberadaan mereka dalam komunitas harus saling memahami 
sebagai antara guru dan murid. Di dalam kultur Sasak, kesetiaan pada guru dijunjung tinggi. Pada kasus Akar Pohon, para penyair muda rela menjadi "kaki"-nya Kiki Sulistiyo. Artinya, mereka siap menjadi pengantar atau tukang ojek dari Sulistiyo. Sebagai contohnya adalah kasus kepemilikan sepeda motor. Bila biaya menerbitkan buliten Replika sebanyak Rp. 200.000,00 saja tidak mampu, hal itu tentu berdampak dari fasilitas untuk bergerak dan mobilitas. Namun, mereka mampu melahirkan komunitas Akar Pohon ditengah kondisi ekonomi yang sulit. Penyiar dan komunitas memang berada dalam kesulitan ekonomi, tetapi peran merka sebagai penjaga nilai tradisi sangat berat.

\section{Strategi Tekstual dalam Dua Antologi Puisi Kiki Sulistyo}

Untuk mencapai posisi dan legitimasi dalam arena sastra Lombok, Kiki Sulistyo menggunakan dua antologi puisinya, yaitu Penangkar Bekisar (2015) dan Di Ampenan, Apalagi yang Kau Cari? (2017). Dalam puisi Penangkar Bekisar, Kiki Sulisityo memilih strategi tekstual dengan estetika postmodern ${ }^{10}$. Estetika postmodern itu berada dalam puisi-puisi Kiki Sulistyo, seperti "Penangkar Bekisar". Puisi itu bercerita tentang perjalanan "seorang buta di depan cermin" yang menjadi seorang juru kabar. ${ }^{11}$ Dalam tulisan yang lain, Satrya menguraikan representasi diri dan perjalanan Kiki Sulistyo sebagai seorang panyair. Satrya (2015, h.12) mengatakan bahwa "Kiki bertemu dengan "peracik suara”, "pemancing”, "peniup harmonica", "pelaut tua", "pengayuh perahu samsara", "cantara", "rumah perias jenazah", "makam juru timbang", "tikungan", "si tinggi lidah", "tamsil air mata", "lembah malaria", "sampan tembolak", "orang belangar", "penujum dari jelantik", "pembayun”, "juli jempana”, "rumah tikah", "mata puan", "hantu kupu-kupu", dan "mulut gang". Selanjutnya, Kiki menggambarkan sebuah dunia dan peristiwa seperti "mauled", "ogohogoh di cakra", "luka mandalika", "suluh zaratusthtra".

10 Estetika postmodern dalam puisi Kiki Sulistyo dijelaskan oleh Satrya HD dalam sebuah diskusi bulan budaya tanggal 28 september 2015 di Museum Negeri Nusa Tenggara Barat (NTB)

11 Makalah diskusi bulan budaya NTB, 28 September 2015 Musium NTB, h 12-13 
Pertemuan itu membuatnya menjadi penyair. Dia juga menjadi juru kabar dan sekaligus menjadikannya borjuis yang berusaha bergerak menaiki tangga sosial. Hal utama yang kedua dalam tulisan tersebut adalah penggambaran dunia yang dilakukan oleh Kiki Sulistyo. Dalam puisi tersebut, Kiki $\quad$ Sulistyo menggambarkan dunia yang dilaluinya dalam perjalanan dengan sudut pandang subjektif dan berjarak (Satrya, 2015, h.11). Dalam puisi Di Ampenan, Apalagi yang Kau Cari?, Kiki Sulistyo memasukkan Ampenan, sebuah kota tua di Lombok, dalam peta sastra Indonesia. Dalam antologi puisi itu, Kiki Sulistyo menulis tentang hikayat Ampenan, sebuah peta kecil tentang Ampenan, kenangan tentang beberapa orang, kenangan tentang sesuatu yang pernah ada di kota tua itu. Kesimpulannya, kota Ampenan dijadikan sebuah tujuan.

Antologi puisi tersebut adalah sebuah suara dari pinggir ${ }^{12}$. Kiki

12 Suara dari pinggir adalah sebuah sikap akademisi dalam cultural studies menyuarakan kaum pinggir. Sikap tersebut tercermin dalam penelitian-peelitian yang
Sulistyo menyuarakan Ampenan dalam dua cara. Antologi puisi tersebut berada dalam isu tentang memori dan pascamemori. Hal ini dikatakan sebagai isu memori karena kota Ampenan dibangun dalam memori tentang keluarga. Sementara itu, hal tersebut dipandang sebagai pascamemori karena kota itu dibangun dalam memori sejarah kota Ampenan yang diingat. Maksudnya adalah ingatan yang menjadi sebuah narasi tentang kota Ampenan.

Fakta tersebut, pertama, dapat dilihat pada puisi-puisi tentang keluarga seperti muncul dalam ungkapan "layar tancap Ampenan", "rumah ladang paman kami", "papuq kebon", "pancing jero kepek", "itje dari Belanda", "sium lim", "paman bun", "kenangan pada bapakku", "bibi kriting", "Januari", "rambut merah

dilakukan Yapi Taum dalam karirnya sebagai seorang akademisi., dalam esai "Sound the Margin: Peran Akademisi dalam membangun Peradaban Bangsa", makalah yang dipresentasikan dalam acara pemilihan Pendidik Berpretasi yang diselenggarakan Kemristekdikti, 28-31 Oktober 2017, h 1-17. Namun dalam tulisan ini, suara dari pinggir ini datang dari seorang penyair untuk menyuarakan etnisitas Sasak-Lombok, NTB, dalam sastra Indonesia. Afrizal Malna menyebutnya sebagai gejolak baru puisi Indonesia, Epilog dalam antologi puisi Di Ampenan, Apalagi yang Kau Cari?. 
ida”, "pegadaian”, "kristik", "pulang ke Ampenan", "tiang tunggu di Kelayu", "enam kwatrin”, “ajarkan aku begaimana memasuki sebuah kota", "hari kepulangan", "laut menatapku", "lubang malam Ampenan", “angin berjalan dari selatan", "Ampenan kemana aku akan menjelang”, "di Ampenan apalagi yang kau cari", dan "hari tua Ampenan kita". Puisi-puisi itu dibangun atas dasar ingatan Kiki Sulistyo tentang rumah dan keluarganya di Ampenan. Selain itu, puisi itu dibangun juga berdasarkan ingatan tentang masa kecilnya di Ampenan.

Kedua, realitas atau fakta yang telah disebutkan dapat dilihat dalam puisi Variasi Hikayat Ampenan. Puisi ini diuraikan dalam enam sajak yang terletak di bagian awal dan akhir. Variasi Hikayat Ampenan dalam puisi pertama berasal dari narasi mitos. Mitos tersebut adalah mitos sejarah Ampenan. Hal ini terlihat dalam katakata atau penanda seperti "dengan serat ampan ia panggil ikan-ikan”, "di tepi bahana pantai belum bernama", "sesaat sebelum tiba pasukan perang", dan "menabuh genderang dari sebrang". Bait puisi tersebut mengidikasikan nama Ampenan yang berasal dari peristiwa "ampen" "benang" yang dipakai dalam memancing ikan. Bait puisi dalam kumpulan puisi Variasi Hikayat Ampenan yang kedua (hlm 61), di bagian akhir kumpulan puisi itu, menghubungkan sejarah Ampenan dengan Seleparang dalam konteks peperangan. Hal ini terlihat dari penanda seperti "daun ampan", "daun ampan tujukkan jalan padaku”, "jalan ke makam Seleparang”, "tunjukkan padaku jalan ke makam seorang pelarian", "yang hilang", dan "yang hilang di tengah halimun peperangan".

Isi dari memori dan pascamemori ${ }^{13}$ masih berada dalam isu sastra pascamodernisme ${ }^{14}$. Isu

\footnotetext{
13 Pascamemori merupakan isu sastra yang menarasikan sesuatu atau persitiwa yang dilakukan oleh generasi kedua yang mengingat sesuatu atau sejarah dari narasi-narasi yang sudah ada. Jika sesuatu dinarasikan oleh penyair sebagai sebuah ingatan seperti keluarga yang dialami langsung, maka sastra yang demikian dapat dikatakan sebagai memori. konsep pascamemori digunakan oleh Bart Ziino (2010) dalam artikel A Lasting Gift to his Descendants, Family Memory and Great War in Australia, dalam jurnal History and Memory, Vol 22, No 2, pp 125-146

14 Sastra pascamodernisme adalah sastrasastra pascakolonial, sastra perjalanan, sastra yang melakukan perlawanan terhadap sastra yang terpusat, termasuk lokal yang menggoyahkan sastra nasional
} 
demikian membawa Kiki Sulistyo mendapat legitimasi sebagai peraih puisi terbaik oleh Kusala Sastra Katulistiwa 2017 pada bulan Oktober 2017 di Jakarta.

\section{SIMPULAN}

Arena sastra Lombok adalah dunia ekonomi terbalik. Para penyair dan terutama yang diwakili oleh Kiki Sulistyo melakukan penyangkalan terhadap ekonomi. Kiki Sulistyo bergerak di arena produksi terbatas sehingga puisinya tidak bisa berada dipuncak hierarki secara ekonomi. Namun, dia dapat meraih simbolik.

Secara ekonomi, puncak hierarki diduduki oleh drama dan diikuti novel. Genre novel diwakili oleh sastrawan borjuis, seperti Agus Fn dan Salman Faris. Bagi penulis borjuis, novel adalah sebuah ekspresi. Bagi penulis borjuis kecil dengan Kiki Sulisityo sebagai wakilnya, puisi adalah sebuah gerakan. Dalam upaya meperkuat puisi sebagai sebuah gerakan, Kiki Sulistyo membentuk komunitas sastra, yaitu Akar Pohon.

Komunitas ini melahirkan banyak penyair muda di Lombok.

\begin{tabular}{l}
\hline dengan masing-masing daerah \\
menyuarakan identitas dirinya.
\end{tabular}

Komunitas tersebut juga menjadi strategi bagi Kiki Sulistyo dalam meraih posisi di arena sastra Lombok. Selain membentuk Akar Pohon, strategi lainnya adalah strategi tekstual. Dia menulis puisi dengan gaya pascamodern. Gaya puisi pascamodern dapat dilihat dalam dua antologi puisinya, yaitu Penangkar Bekisar (2015) dan Di Ampenan, Apalagi yang Kau Cari? (2017). Kedua kumpulan puisi itu mengantarkan Kiki Sulistyo meraih legitimasi dari para penyair dan akademisi sastra. Antologi yang kedua membawanya sebagai peraih kategori puisi Kusala Sastra Katulistiwa 2017, Oktober 2017.

\section{DAFTAR PUSTAKA}

Adilla, I. (2015). "A.A Navis dalam Arena Kesusastraan Indonesia". Disertasi S-3, Fakultas Ilmu Budaya, Universitas Gadjah Mada, (tidak diterbitkan).

Andayani, S. (2014). "Strategi Murakami Haruki dalam Meraih Posisi dan Legitimasi di Arena Sastra Jepang". Tesis S-2, Fakultas Ilmu Budaya, Universitas Gadjah Mada (tidak diterbitkan).

Anwar, S. (2013). "Persada Studi Klub: Disposisi dan Pencapainnya dalam Arena Sastra Nasional". Tesis S-2, Fakultas Ilmu Budaya, 
Universitas Gadjah Mada (tidak diterbitkan)

Astika, I.M. (2013). "Pergulatan Umbu Landu Paranggi dalam Arena Sastra di Bali: Tinjauan Sosiologi Pierre Bourdieu". Tesis S-2, Fakultas Ilmu Budaya, Universitas Gadjah Mada (tidak diterbitkan)

Bourdieu, P. (1977). Outline of theory of practice. Cambridge University Press: USA.

Bourdieu, P. (2011). Choses dites, uraian dan pemikiran. (penerjemah: Nini Rochani) Yogyakarta: Kreasi Wacana.

Bourdieu, P. (1993). Arena produksi kultural, sebuah kajian sosiologi budaya. (penerjemah: Yudi Santosa). Yogyakarta: Kreasi Wacana.

Berger, P. \& Luckmann. (2013). Tafsir sosial atas kenyataan, risalah tentang sosiologi pengetahuan. (penerjemah: Hasan Basari). Jakarta: LP3S.

Day, T. dan Foucher, K. (2006). "Bahasan postkolonial dalam sastra Indonesia modern" Foulcher, K. Dan Day, T. (ed.) (2006). Clearing Space: Sastra Indonesia Modern Kritik Pascakolonial. Jakarta: Yayasan Obor Indonesia, h 1-25

Derk, W. (2006). "Sastra pedaleman: pusat-pusat sastra lokal dan regional di Indonesia" dalam Foulcher, K. dan Day, T (ed.). (2006). Clearing a Space: Sastra Indonesia Modern Kritik Pascakolonial. Jakarta: Yayasan Obor Indonesia.

Karnanta, K.Y. "Sastra "Mungkin": kontestasi simbolik Andrea Hirata dalam arena sastra Indonesia" dalam Jurnal Poetika,
Vol III No 2 Desember 2015, pp 11-21

Mustansyir, R. (2012). "Dimensi tanda dalam perspektif analitika bahasa Ludwig Witgenstein dan pengaruhnya dalam tanda kontemporer" dalam Jurnal Filsafat Universitas Gadjah Mada. Vol 22 No 1, April 2012. pp 1-17.

Nugraha, L. (2015) "Strategi, Agen, dan posisi Emha Ainun Najib di arena sastra dan arena sosial" dalam Jurnal Poetika Vol III No 2, Desember 2015 pp 22-34.

Satrya, H.D. (2015) "Sebuah perjalanan: diri dan puisi dalam penangkat Bekisar karya Kiki Sulistyo" dalam makalah, Bulan Budaya Nusa Tenggara Barat (NTB) di Musium NTB.

Satrya, H.D. (2016). "Posisi dan Disposisi Agen Sastra di Lombok", dalam kumpulan makalah Isu-Isu Mutakhir dalam Kajian Bahasa dan Sastra, September 2016, Yogyakarta, Fakultas Ilmu Budaya UGM, pp 442-455.

Satrya, H.D. (2014) "Esti Nuryani Kasam: kajian feminis dengan perspektif sosiologis". Bunga Rampai Kajian Sastra, Yogyakarta: Bolak-Balik, pp 225-236

Safitri, A.N. (2015). "Pergulatan imam Budhi Santosa untuk mencapai posisi terkonsekrasi dalam arena sastra Yogyakarta" dalam Jurnal Poetika, Vol III No 2 Desember 2015 pp 44-51

Sulistyo, K. (2015). Penangkar Bekisar, sehimpun puisi. Bandung: Nuansa Cendikia

Sulistyo, K. (2017). Di ampenan, apalagi yang kau cari?. Yogyakarta: BasaBasi 
Sulistyo, H. (2015) "Korelasi modal terhadap kontestasi arena dan praktik Feba Sukmana penulis novel Holland: One Fine Day In Leiden dalam Aspek Pasar, Narasi, dan Penggunaan Bahasa". dalam Jurnal Poetika Vol III No 2 Desember 2015, pp 35-43

Tjahyadi, S. (2008). "Manusia dan Historisitasnya Menurut Martin Heidegger", dalam Jurnal Filsafat Universitas Gadjah Mada Vol 18 No. 1, pp 47-58.

Yapi, Y.T. (2017). "Sounds of the Margins: Peran Akademisi dalam Membangun Peradaban Bangsa", Makalah yang dipresentasikan dalam acara pemilihan Pendidik Berpretasi, Kemristekdikti, 28-31 Oktober 2017, h 1-17.

Zamzuri, A. (2016) "Bengkel Sastra Balai Bahasa DIY dalam Perspektif Sosiologi Pierre Bourdieu" dalam Prosiding Seminar Nasional Paramasastra 4: Bahasa, Sastra, dan Pengajarannya dalam Paradigma Kekinian, 2016. Surabaya: FBS Universitas Negeri Surabaya.

Ziino, B. (2010). "A Lasting Gift to his Descendants, Family Memory and Great War in Australia" dalam Journal History and Memory, Vol 22, No 2, pp 125146 